\title{
The Legal Study of a Legal Entity as a Recipient of Custody Testament in Article 108 of KHI and Its Relevance to The Principles of Maqāṣid al-sharī’ah
}

\author{
$1^{\text {st }}$ Muhammad Alwi al Maliki ${ }^{1}, 2^{\text {nd }} J M$ Muslimin ${ }^{1}, 2^{\text {nd }}$ Khamami Zada $^{2}$ \\ \{muhammad_maliki19@mhs.uinjkt.ac.id ${ }^{1}$, jm.muslimin@uinjkt.ac.id ${ }^{1}$, khamami@uinjkt.ac.id² $^{2}$ \}
}

UIN Syarif Hidayatullah, Islamic Studies Department, Jakarta, Indonesia ${ }^{1}$, UIN Syarif Hidayatullah, Sharia and Law Department, Jakarta, Indonesia ${ }^{1}$

\begin{abstract}
This research aims to analyze a regulation of custody testament in article 108 of KHI, and its relevance with the principles of Maqāsid al-shariah by using the method of interpretation approach for the provisions of the custody testament in KHI, marriage law no. 1 of 1974 and the Eropa's Civil Code. This research focuses on a custody testament which is given to a legal entity. The method used in the research is the descriptive qualitative method by the method of interpretation approach. This study produces conclusions about the provisions of the custody testament in article 108 of KHI has responded the changing of times and it has relevanted to the principles of Maqassid al-shariah but it must be further refined to be clearer. The author recommends the government to give additional explanations in article 108 of KHI so that the principles of Maqāssid al-sharīah will be reached completely.
\end{abstract}

Keywords: testament, custody, legal entity, article 108 of KHI, maqāṣid al-sharī’ah

\section{Introduction}

A testament is one of the ways of administering wealth governed by Islam. [1] In some classic literature, the discussion of testament is included in the chapter of inheritance because of the interrelation between the two in a person who owns the property. The testament occurs before the person passes away, while the inheritance occurs after the person has passed away but the implementation of both is done when the person has passed away. Besides, there is also a testament to responsibilities such as a testament to childcare, asset management, and others relating to the testator by himself. [2]

Compilation of Islamic Law is a manifestation of the Islamic law that has "interacted" with the social and cultural realities of the Indonesian people so that produce Islamic Indonesian legal products. [3] As a regulation used by Judges in the Religious Courts, KHI contains the civil code for the Muslim community. [4] KHI consists of three parts: Book I contains the Marriage Law, Book II contains the Inheritance Law, Book III contains the Waqf law, and in the end, there is an explanation of the articles overall. [5]

In the book I regarding marriage law exactly in article $108 \mathrm{KHI}$, it is mentioned that parents can inherit the right of custody of themselves and the wealth of children to someone or legal entity when they has passed away. [5] This is different from the explanation in the 
general provisions of Book I letter (h) which reads "custody is the authority given to someone to do something as a representative for the interests and on behalf of children who do not have both parents, parents those who are still alive are incapable of carrying out legal actions." In the general provisions the term "legal entity" is not mentioned as the recipient of the custody rights. Besides, there is no further explanation regarding the legal entity referred to this article at the end of KHI so that the legal certainty on this article is still questionable.

Law no. 1 of 1974 also does not mention provisions relating to legal entities. [6] Furthermore, in the Civil Code, the legal entity provisions are mentioned in Book III on Commitments - The ninth chapter on Legal Entities starting from articles 1653 - 1665 of the Civil Code. While the testament is mentioned in Book II about Thirteenth and Fourteenth Chapters. While the custody is mentioned in Book I about the person on the Fifteenth chapters. [7]

Discussions related to testament and custody have been discussed several times before. Some of them are like what Achmad Hadi Sayuti had done in his thesis entitled "Marriage Custodians in Perspective Two Madhhab and Positive Law". This research concludes that the difference between custodian requirements in marriage to the al-Shăfi'i madhhab and the Hanafi madhhab of thought lies in the way of formulating the law between the two. According to him, this was influenced by different social conditions in the place of the two of them. Imam al-Shāfi'i, who lives in Egypt, intersects with the marriage tradition of girls aged 10-15 years, so the custodian's permission in marriage is needed. While the social setting in Kufa as a cosmopolitan city and center of civilization makes the age of marriage for women ranges from the age of 18-22 years so that they are considered able to choose and determine their marriage without the consent of the custodian. [8]

Another study by Mochammad Charistal Chubba in his thesis entitled "Analysis of Islamic Law on article $108 \mathrm{KHI}$ about the Custody of Children to Legal Entities". This study concludes that Article $108 \mathrm{KHI}$ does not have a legal basis in the text of the Qur'an and Hadith and there are no explanatory provisions in the custodian of that article. Besides, the provisions of custody to legal entities are contrary to norms that are for the life of the community. [9]

The purpose of this research is to analyze article $108 \mathrm{KHI}$ concerning the legality of a legal entity as a recipient of custody testament for the self and wealth of children who left behind by their parents from a normative juridical perspective with historical and systematic interpretative analysis of the testament and custody provisions in KHI with Islamic law and other legislation regulations, in this case, are statutes no. 1 of 1974 and the Civil Code. Besides, this study also aims to analyze the relevance of legal entities in article $108 \mathrm{KHI}$ with the principles of universal benefit in Islam (Maqāșid al-sharì'ah).

\section{Research Methodology}

This research is a normative legal research. According to Soerjono Soekanto that normative legal research revolves around five things: 1) research on the principle of law; 2) research on legal systematics; 3) research on legal synchronization; 4) research on the history of law; 5) research on legal comparisons. [10] The technique of collecting data uses document studies. [10] Whereas in analyzing the data the author uses descriptive analytical techniques with a historical and systematic interpretation approach. Next, the processing of data the author uses editing and organizing techniques. [11] 


\section{Finding}

\subsection{Testament}

Etymologically, the testament comes from the word awșa-yūṣ $\bar{l}$ which means message, order, and advice. [12] In classical Jurisprudence, the definition of testament is derived from the word wașaitu al-shai'a (I gave a message about something). A person who has the testament tells something he has in his life to be utilized when he has passed away. [13]

In Islamic law, the terminology of testament is mentioned as a message delivered by a testator verbally or in writing related to private ownership in the form of rights, property, or the use of goods to others voluntarily and carried out after the testator passes away. [14]

The testament has been mentioned in the Qur'an and the hadith of the Prophet Muhammad. The testament in Quran is mentioned 32 times [15] with several different word derivations in several verses including وصى, أوصى, تواصوا, يوصى, موص, وصية, نوصية. As for some of the derivations of the word has different meanings such as order, advice, messages, mandatory, related provisions in inheritance and others.

The testament is mentioned twice in KHI, first in article $108 \mathrm{KHI}$ and secondly in book II on inheritance law. The definition of a testament is found in the general provisions of the inheritance law letter (f) which reads "a testament is the giving of an object from a testator to another person or institution that will take effect after the testator has passed away." [5] In this terminology, there is a reduction in the definition of a testament that is limited to wealth.

In the statute no. 1 of 1974 the testament is mentioned once in chapter XI about representation in article 51 which reads "custodian can be appointed by one parent who exercised parental authority, before he passes away, with a testament which is written or orally before two signatories." in this statute and in PP no. 9 of 1975 as the base for implementing the law the definition of testament is not explained.

The discussion of the testament is found in Book II Chapters XIII and XIV of the Civil Code. The definition of a testament is contained in article 875 which reads "A testament is a document containing a person's statement about what he wants to happen after he has passed away that can be removed by him." [7] there is different regulation in Islamic classical law and KHI with the Civil Code. In Islam, a testament can be done in two ways: oral or written witnessed by two people. Whereas in the Civil Code, a testament is only considered valid if it is written and notarized whether it is open or closed.

\subsection{Pillars and Requirements of Testament}

The Sholars argue that a will has several pillars and requirements that must be met. Pillars and requirements will include [16]:

1) testator $(a l-M \bar{u} s \grave{i})$

2) recipient/beneficiaries (al-mușā lah),

3) something inherited (al- mușā bih),

4) sighat both orally and in writing.

While the requirements of a testament are some of the criteria that each testament must have. these include:

1) Testator

There are several requirements that must be fulfilled by the testator, namely: a) capable of law (tamyizz); b) independent; c) Bāligh, related to this issue are different opinions of scholars. The Malikiyah and Hanabilah followers allow the testament of a child who is capable of law 
even though he has not reached bāligh period; d) understanding; e) fair; f) testator is the owner of something that is inherited in its entirety; g) voluntary will, and h) free from debt. [17]

2) Beneficaries

Some requirements for the recipient of a testament are as follows: a) able to receive a testament; b) competent in law [19]; c) specifically and clearly appointed; d) is not prevented from receiving a testament; e) is not a kāfir harb; f) is not a recipient unless agreed to by other inheritors. [17]

3) Something inherited

Something that testament be inherited have several requirements namely: a) useful; b) can be utilized; c) something that is lawful; d) not used for immorality; e) the property of the full estate testator; f) not more than $1 / 3$ of the estate's testator. [17]

4) Redaction of testament

The redaction of a testament in fiqh can be conveyed clearly or vaguely (not with a writing testament) by verbally or in writing witnessed by two people. As for the times and social conditions, it demands legal certainty and guaranteed transactions. Therefore the editorial will be clear and written in the presence of two people. [18]

\subsection{Custody}

Etymologically, wāli is a ism fail from the wilayah that begins from the word waliya yaliy which has various meanings by the siyaq of its words such as mastering, caring, loving, helping, entrusting, making friends, turning away and others. [12] Whereas the Big Indonesian Dictionary, it have several definitions depending on the use and context of the discussion. Some of the meanings are as follows: 1) means that those who are legally entrusted with the obligation to guarantee, care for orphans themselves and property before adulthood; 2) A person who has the authority to marry a girl who is still a girl or a widow; 3) Godly and religious exclaimers; 4) head of government and others. [19]

The custody comes from the word wilayāh or walayāh which means care and protection. [12] According to Mardani, custody is a trust entrusted to someone to act on behalf of the law as a representative in the affairs of children whose parents have passed away or are not capable of law. [20] This is in line with the opinion of Muhammd Abu Zahrah who explained that custody occurs in three situations: 1) in childcare (had̄annah);2) in preserving the lives and property of children who have passed the age of the hadānah period but have not yet reached the bāligh period; 3) in the management of assets of people who have reached the bäligh period but have had mental disability (idiots, epilepsy) and / or crazy. [21] In essence, custodian and custody come from one ground word. The position of the costudian is as an actor or subject and custody is a form of work. Therefore, a custodian in the terminology of Islamic law is someone who is given the authority to do custody to take care, care for and protect other people or objects that are entrusted to him.

The term of custodian appears twice in different chapters in KHI. First, the marriage custodian in the chapter of the pillars and requirements of marriage and second, custody in a separate chapter governing the self and property of minors. In this second custody, article 108 states that custody is defined as a right that is inherited by parents to a person or legal entity. Whereas in the book I about Marriage Law it is not explained at all about the provisions of a will regarding the trust rights. Related provisions are only mentioned in book II about inheritance law which in no way addresses the validity of the rights and responsibilities of the testament as something that can be inherited. 
In the Civil Code, Custody is regulated in Book I of Maturity and custody Chapters. In that chapter, custody is limited to immaturity. [7] This is understandable because the Civil Code is a western civil law that does not require a custodian in marriage.

There are two types of custody in Islamic law: 1) wilayah 'ala al-nafs (custody of the soul and self); and 2) wilāyah 'ala al-māliyah (custody of assets). [21] Whereas in KHI, custody is mentioned for two conditions: 1) marriage custody (article $19 \mathrm{KHI}$ ); and 2) custody of minors. [5] In Law no. 1 of 1974, custody is only mentioned in the case of custody of minors in chapter XI concerning representation. [6] Whereas in the Civil Code the custody is limited to one's immaturity. Nevertheless, the provisions of the custody are discussed in detail. [7]

A custodian, in Islamic law, must have several criteria, including:1) Muslim;2) Sensible;3) Bāligh;4) Competent and capable;5) male (for custody in marriage). [21] In KHI, a custodian as regulated in article 20 verse (1) "who acts as a marriage custodian is a man who fulfills the requirements of Islamic law namely Muslims, aqil and bāligh." [5] Whereas in article 107 verse (4) "custodian as far as possible -can be taken from the child's family or other people who are adults, think healthy, fair, honest, and of good character or legal entity." [5]

In statutes no. 1 of 1974 article 51 verse (2) "custodians should be taken from the child's family or other people who are adults, think healthy, fair, honest and good behavior." [6] In the Civil Code, there are several provisions related to the criteria of custodians. These provisions relate to differences in the way the appointment of the custodian. In general, the criteria required are custodians appointed by judges or parents, either in the form of individuals or associations, foundations or social institutions that are capable of custody and are willing to fulfill them. [7]

The custody in Islamic law has the right to be carried out by: 1) Custodians of the Nasab; 2) Sultān as the legal custodian; 3) someone who is appointed as custodian based on the testament of his biological father, both from his family or other trusted persons. In this case, the scholars differed. In general, scholars agree that parents - in this case, the real father - may leave to others as custodians of their children when he has passed away. Whereas in his position as custodian of marriage, some of the scholars disagree. The Shāfi'i scholars state that a wāli wāṣi cannot be a marriage custodian for the girl, this opinion as explained in the book of al-hāwi al-kabīr. [22] The scholars who allow are from the group Mālikiyah and Hanābilah. They argue that the position of wāli wāși is the same as the biological father so he also has the right to be the marriage custodian of the girl. [23]

The custody in KHI can be carried out by:1) Custodians of the nasab; 2) Head of KUA who has the duty as judge's custodian; 3 ) Someone who is appointed as custodian based on the testament of a parent either from a family or other person individually or in the form of a legal entity; 4) custodian by order of Judges of the Religious Courts. [5] Whereas in statute no. 1 of 1974 the rules of custody are almost the same as KHI, except that there is no rule for the Head of KUA to be the custodian of the judge and in the custody, the custody is only limited to families or other trusted persons without entering a legal entity. [6] Furthermore, custody in the Civil Code can be done by: 1) Both Parents; 2) a person or association, foundation or social institution appointed as custodian by parents; 3 ) a person or association, foundation or social institution that is ordered as a custodian by a District Court Judge. As for associations, foundations or social institutions that are appointed or governed must be domiciled in Indonesia and its articles of association, there are rules for caring for minors. [7] 


\subsection{Legal Entity}

The discussion of legal entities as legal subjects that can accept testament and become custodians is not found in Islamic law or statute 1 of 1974. Discussion of legal entities contained in the Civil Code and KHI. The legal entity in the Civil Code in article 1653-1665. Legal entities as legal subjects have several formal and material requirements that must be met. The formal requirements referred to : 1) a legal entity established based on a notarial deed; 2) has an Statutes and bylaws; 3) authorized by the authorized Minister; 4) announced in the Official Gazette; 5) registered with the Registrar of District Court authorized.Furthermore, the material requirements for a legal entity are: 1) clear separation between the legal assets of the legal entity and the personal assets of the management/members; 2) have specific goals that are directed and ideal; 3) have clear interests; 4) has a clear organizational structure; 5) has a clear operational area and place of practice. [24]

\subsection{Epistemology of Maqāsịid al-sharīah}

Maqāṣid al-sharīah in language consists of two words مقاصد and مقاصد. شريعة is the plural form of the word sقصد which has various meanings such as fair, middle and not crossing the line. [25] Whereas شريعة is the path to the spring, al-Raysuni explains that what is meant by sharia is many practical laws both related to the concept of 'aqidah and Islamic legal legislation. [26] Whereas in terminology, Maqāssid al-sharī'ah is wisdom, meaning, and purpose desired by Allah as the maker of sharia. [27]

The core discussion of Maqạsid al-shariah is about maintaining the benefit and resisting danger. This is in Islam is called jalb al-mașlahah and dar'u mafsadah. Mașlahah and mafsadah are two things that underlie the emergence of the concept of Maqāsid al-shariah. The existence of the two cannot be united in one problem. When it brings mașlahah, it certainly removes mafsadah. And vice versa, removing mafsadah is a benefit.

Etymologically meaningful of mașlahah is derived from the root word șaluha. Is a form of mufrad of al-mașālih. [12] In the șarraf discipline, mașlahah matches meanings with manfa'ah meaning something beneficial, and useful. [28] Whereas in terminology, ushul scholars differ in their opinions in defining it. However, the difference can be drawn from the difference that benefit is the essence of the sharia and an integral part of the formulation of Islamic law. This is based on the objectives of the sharia that Allah sent down to the prophet Muhammad to preserve and care for the good of people and prevent them from danger. [29]

The division of mașlahah in some literature is divided into several types. When viewed from the aspect of the need for humans is divided into three: a) Darūriyyāt; b) Hājiyāt; c) Tahsiniyät. [30] When viewed from the aspect of its existence is divided into three: a) Mu'tabarah; b) Mulghāh; c) Mursalah. [29] When viewed in terms of scope it is divided into three: a) 'āmah; b) khāsh; c) juz'iy. [31]

Al-Shattibi has explained that the maslahah referred to is the real benefit (mașlahah haqiqi), that is, mașlahah based on the sharia of God so that protecting it is to establish the objectives of the sharia of Allah. Unlike the case with maslahah from a human point of view based on lust, mașlahah in this context is a benefit that is in line with sharia. [32]

The provisions of something that can be called mașlahah which can be used as hujjah, scholars differ in their limits. Here are some scholars related to the limitations of the problem above.

1) Limitation of Mașlahah according to al- Shāțibi 
Al-Shatibi provides the following criteria for mașlahah: a) Maṣlahah has a universal scope; b) Mașlahah has essential benefits; c) It does not conflict with the problem of mu'tabar; d) Form the basis ('illat) of a law; e) Prioritize common problems. [32]

2) Limitation of Mașlaḥah according to al-Būṭi

The mașlahah limit according to al- Būți there are 5 main points as a measure of mașlahah can be used as hujjah as presented in his dissertation treatise, dawābit al-mașlahah, including: a) Within the scope of sharia objectives; b) Does not contradict the Qur'an. c) Does not contradict the Sunnah; d) Does not conflict with qiyās; e) Does not conflict with a more urgent benefit. [33]

\section{Discussion}

\subsection{Discussing on Article 108 of KHI}

KHI as a guideline for the settlement of civil cases of Muslims was born from the results of a long and comprehensive discussion involving many groups ranging from scholars to academics. The main sources of the formulation are several books that are recognized (mu'tabar) for their credibility in solving legal problems. The majority of these books were written by scholars of the Shafi'i madhhab. Besides, customary law in force in Indonesia is also taken into consideration in the formulation of KHI because after all the historical reality of the Indonesian nation needs to be considered so that the legal products produced are appropriate and targeted. Besides, several laws from other countries are also made into comparisons as an effort to consider the KHI concept that will be formulated such as Morocco, Turkey, and Egypt.

Article $108 \mathrm{KHI}$ contains custody rules that may be passed on by parents to other people or legal entities. Such a testament can also be found in Islamic law (fiqh), which is the opinion of the scholars of the 4th Imām of madhhab about the ability to give custody authority using a testament to someone who is believed capable and trusted to accept that authority. Whereas, in the area of authority of a wāli wāṣi, they have different opinions. Imām al-Shāfi'i and Imām Abu Hanīfah argue that the authority of a wāli is limited to self-care for orphans and property until he is an adult. While Imām Mālik and Imām Ahmad ibn Hanbāl argue that the position of $w \bar{a} l i$ waș $\mathbf{i}$ for orphans is like the position of his biological father so that everything that is a father's rights and obligations to his son also applies to the custodian including being a custodian in her marriage as long as it is inherited publicly without there are certain conditions that state otherwise.

The custody referred to article $108 \mathrm{KHI}$ is custody for minors who died by their parents and have not been able to regulate themselves and their assets. This is different from custody in marriage. Marriage custodian in KHI is only limited to wāli nasab and custodian of the judge (wāli hăkim). The custody by testament (wāṣi) is not used by KHI as a rule of law even though the wāli wāṣsi was allowed in marriage by Imām Mālik and Imām Ahmad ibn Hanbāl. Therefore, it can be understood that the provisions of the custody testament in KHI are motivated by the opinion of fiqh scholars. The difference between the provisions in fiqh and $\mathrm{KHI}$ is the emergence of a legal entity as a legal subject receiving custody. 


\subsection{Discussing on The Legal Entity Position as a Recipient of a Custody Testament}

Legal entities as legal subjects receiving custody rights are regulated in article $108 \mathrm{KHI}$. But no explanation constitutes of a legal entity's criteria for receiving custody. The findings of the explanation of a legal entity as a custodian has found in the Civil Code. Legal entities in the Civil Code have several criteria that must be met to receive a custody mandate. This is mentioned in article 365 of the Civil Code. But since articles 50-54 of statute No. 1 of 1974 applies, the custody provisions in the Civil Code are no longer valid.

In statute no. 1 of 1974 the custody is regulated in chapter XI concerning Representatives article 50-54. In the provisions of the custody in this verse, it is not stated that a legal entity can be the recipient of a testament in the custody granted by a parent. The provisions in this verse only state that the custodian testament for themselves and the assets of a minor are as much as possible from their immediate family. In this case, the provisions contained in statute no. 1 of 1974 reduced the provisions contained in the Civil Code regarding the testament to the custody rights of minors that can be mandated to legal entities in the form of associations, foundations of social institutions domiciled in Indonesia and in its statutes and bylaws of association there are rules for the care of minors.

The existence of a legal entity as custody in article $108 \mathrm{KHI}$ raises a pretty basic question because there is no explanation either in the form of the article or in the explanation section. The legal entity in that article also has no connection with the article before or after except in article $107 \mathrm{KHI}$ which states "custodian should be taken from the child's family or legal entity to provide trust for themselves and the wealth of the child or children after he dies."

If examined from its history, the emergence of KHI is motivated by several things including:

1) Complement the judicial technical needs of the Religious Court [34]

2) Uniformity of perception in law enforcement [35]

3) Legal certainty that has not been fully achieved [36]

From the history above, it can be understood that the emergence of KHI is motivated by several matters relating to the technical needs of the Religious Courts and efforts to uniform the judges' perceptions in deciding cases for the achievement of full legal certainty in decisions issued by judges of the Religious Courts.

Furthermore, KHI as a fiqh representation that has a dialogue with tradition and culture and social reality in Indonesia, has a foothold and a limitation in its legal formulation. This is done to maintain the principles of mașlahah that already exist in classical Jurisprudence products and on the other hand, can respond to the development of the age that is happening in Indonesia. Some of the things that become the reference in the KHI legal formulation method are as follows [3]:

1) Guided by the values of universal benefits in Quran and al-sunnah.

2) Resolving the newest problems becomes a priority

3) Indonesian socio-cultural conditions become ground characteristic

\subsection{Analysis of Legal Entity as recipient of Custody Testament in Article $108 \mathrm{KHI}$}

The emergence of a legal entity in article $108 \mathrm{KHI}$ which seems groundless can be found a solution by carrying out historical interpretations. In the method of historical interpretation, legal products are viewed from aspects of the history of law and the history of the occurrence of the law. In this case, the term legal entity in the discussion of custody in KHI is inseparable from the formation of the drafting team involving scholars and academics. 
Besides, the purpose of KHI is to respond the development of the times by still referring to the provisions and boundaries that become the reference for legal formulation as mentioned earlier. Therefore, from the perspective of the formation of KHI, the provisions of the legal entity in article 108 are a legal breakthrough step that is anticipatory to the times.

Changing times which is a necessity allows everything to change including the rule of law. Besides, several Islamic social foundations and institutions that stand either in the name of private associations such as orphanages specifically for Muslim orphans or in the name of religious social organizations such as Nahdlatul Ulama orphanages or Muhammadiyah orphanages since this regulation are in the formulation process to the present has emerged and developed. The existence of these institutions in Indonesia is very beneficial for people who might want to have a testament but do not have families or they have families but cannot be trusted. Therefore it is necessary to formulate rules that accommodate these predictable needs. The point is that if there is such a thing, there is a rule of law that can be the basis for a judge's decision in the Religious Court or be a recommendation for citizens who need a solution to the problem.

The unclear criteria for legal entities in article $108 \mathrm{KHI}$ both in terms of the absence of explanation in the next article or the explanation section of the articles as a whole can be found a solution by doing a systematic interpretation. In a systematic interpretation, the law is seen as a unit, as a system of regulations. In practice, this method is used to synchronize legal rules that are not yet clear or that require more explanation by looking for related terms in other legislation.

In this case, as explained above, the writer found the legal entity criteria in articles 16531665 of the Civil Code about legal entities that have criteria in the form of formal and material conditions like what has explained before.

The religious problems of the legal entity can be resolved by referring to the points contained in the Civil Code articles such as those contained in the legal requirements of the legal entity which must have a specific, directed and ideal purpose in the sense that the existence of the related legal entity must be clearly the statutes and bylaws. Furthermore, the legal entity must have a clear interest, in the sense that the legal entity must be clear in what way it provides services. Moreover, it has a clear legal structure and territory, in the sense that the legal entity is known for its management. Besides, in general, human reason, a person who wants to inherit the interests of his children will not be arbitrary in choosing a foundation or social institution that he will trust as custodian of children when they have passed away. Besides, the number of Islamic-based foundations and social institutions increasingly dismissed the negative possibilities that occur in the religious aspect.

\subsection{Analysis of The Relevance of Article 108 KHI to The Principles of Maqāṣid al- sharì'ah}

Based on the explanation of some findings and analysis of article $108 \mathrm{KHI}$ above, the author tries to analyze the relevance of article $108 \mathrm{KHI}$ with the principles of maqassid alshari'ah. The custody testament in article $108 \mathrm{KHI}$ is intended to safeguard minors and their wealth by inheriting the custody rights of their biological father to other people who come from close families or people who are believed to be able to carry out the mandate or legal entity. From this, it can be detected several sharia objectives that seek to be maintained. Some of these goals include:

1) Maintaining religion (Hifz al-Dīn) 
The purpose of this Sharia in the case of Article $108 \mathrm{KHI}$ is found in the existence of Article $108 \mathrm{KHI}$ itself which becomes the regulation of Muslim citizens in Indonesia so that its existence becomes one of the intermediaries or to uphold Islamic law (testament and custody) legally and formally.

2) Maintaining body and soul (Hifz al- Nafs)

The purpose of this Sharia is in the effort to protect children by way of inheritance to the care of their immediate family or to other people or legal entities that are trusted and able to carry out good custody.

3) Maintaining reason/ intellegence (Hifz al- 'Aql)

As the goal of self-care, in article 108 the purpose of sharia mind-care lies in the effort to protect the child by inheriting himself, in this case, there is also an element of education as a provision for children to face challenges in the future.

4) Maintaining property (Hifz al-Māl)

The purpose of this Sharia is to protect the assets of minors who have died by their parents through a custody to the family or other persons or legal entities that are believed to be able to maintain and manage the child's finances until he is an adult and can manage his own life.

5) Maintaining Honor (Hifz al-'Irdh)

Maintenance of honor in article $108 \mathrm{KHI}$ is contained in the efforts of protection by parents to their children using a testament that aims to anticipate the bad possibility that occurs when they die and the age of the child is still a minor. It aims to avoid the danger of exploitation of minors by people who are not responsible.

The mașlahah aspects of article $108 \mathrm{KHI}$ when viewed in terms of the urgency of human needs in general, including to the mașlahah hajiyyah with which ultimate benefit can be achieved in the form of preserving the religious aspects, aspects of the soul, aspects of intellect, aspects of property and aspects of respect both parents and children and their property. In terms of its existence, the article includes the problem of mu'tabarah whose instructions are contained in the Qur'an regarding the testament and custody of minors. While in terms of scope, the article is classified as mașlahah khāsșah which is specialized for people with an interest in the custodian of testament.

If examined further, differences in the ability of each person to understand the law in the article in the statutes and KHI produce differences in understanding that may lead to conflict in applying the rules in the article. As an anticipation step, it is necessary to raise an explanation regarding the legal entity referred to in article $108 \mathrm{KHI}$ so that it can be easily understood by everyone who needs the article.

\section{Conclusion}

Based on the research conducted by the author and the data and analysis previously presented, this research resulted in 1) a legal entity as a trustee in article $108 \mathrm{KHI}$ is a legal breakthrough made by the KHI drafting team as an anticipatory step to respond to the times. Furthermore, the unclear criteria for legal entities can be found in a solution using the method of systematic interpretation by synchronizing the provisions of the legal entity in the Civil Code with the legal entity in article $108 \mathrm{KHI}$. The relevance of article $108 \mathrm{KHI}$ with the principles of maqūṣid al-sharī'ah is found in several aspects, namely aspects of religion, body 
and soul, reason, wealth, and honor. In addition, an explanation of article $108 \mathrm{KHI}$ is needed so that everyone can easily understand and the benefits of the article become more perfect.

\section{Acknowledgments}

We would like to thank all of the academic community of the Graduate School of UIN Syarif Hidayatullah Jakarta, especially to Prof. Dr. Jamhari, MA. as the director of the Graduate School of UIN Syarif Hidayatullah Jakarta, Dr. JM. Muslimin, MA as the supervisor and thank to the Ministry of Religion of the Republic of Indonesia for giving us a PMLD scholarship.

\section{References}

[1] Fatchur Rahman, Ilmu Waris. Bandung: Al-Ma'arif Bandung, 1975.

[2] Sulaiman Rasyid, Fiqh Islam. Bandung: Sinar Baru Algesindo, 2008.

[3] dkk Cik Hasan Bisri, Kompilasi Hukum Islam dan Peradilan Agama dalam Sistem Hukum Nasional. Tangerang Selatan: Logos Wacana Ilmu, 1999.

[4] JDIH BPK RI. (2017) bpk.go.id. [Online]. https://peraturan.bpk.go.id/Home/Details/46804/uuno-7-tahun-1989

[5] Abdurrahman, Kompilasi Hukum Islam di Indonesia, 4th ed. Jakarta: Akademika Pressindo, 2010 .

[6] KEMENAG RI. kemenag.go.id. [Online]. kemenag.go.id/file/dokumen/UUPerkawinan.pdf

[7] BPKP. [Online]. http://www.bpkp.go.id/public/upload/unit/maluku/files/Viewer.js/Peraturan/Hukum/KUHPPerdata-Bagian-1.pdf

[8] Achmad Hadi Sayuti, "Nikah dalam Perspektif Dua Madzhab dan Hukum Positif," UIN Syarif Hidayatullah Jakarta, Tangerang Selatan, Bachelor Thesis 2011.

[9] Mochammad Charistal Chubba, "Analisis Hukum Islam terhadap Pasal 108 KHI tentang Wasiat Perwālian Anak kepada Badan Hukum," UIN SUNAN AMPEL SURABAYA, SURABAYA, Bachelor Thesis 2018.

[10] Soerjono Soekanto, Pengantar Penelitian Hukum. Jakarta: UIN Press, 2010.

[11] Abdul Kadir Muhammad, Hukum dan Penelitian Hukum. Bandung: Citra Aditya Bakti, 2004.

[12] Ahmad Warson Munawwir, Kamus al-Munawwir Arab-Indonesia Terlengkap. Surabaya: Pustaka rogressif, 2007.

[13] Abu Bakar ibn Muhammad al-Husaini, Kifāyah al-Akhyār fì Halli Ghāyah al-Ikhtișār. Beirut: Dar al-Kutub al-Ilmiyyah, 2001.

[14] Abd. Shomad, Hukum Islam: Penormaan Prinsip Syariah dalam Hukum Indonesia. Jakarta: Kencana, 2010.

[15] Muhammad Fuad Abd al-Baqi, al-Mu'jām al-Mufahras li alfāż al-Qur'ān. Kairo: Dar al-hadis.

[16] Abdul Manan, Aneka Masalah Hukum Perdata Islam di Indonesia. Jakarta: Kencana, 2006.

[17] M. Fauzan Andi Syamsu Alam, Hukum Pengangkatan Anak Perspektif Islam. Jakarta: Kencana, 2008 . 
[18] Ahmad Rofiq, Hukum perdata Islam di Indonesia. Jakarta: RajaGrafindo, 2013.

[19] KEMENDIKBUD RI. kemendikbud.go.id. [Online]. https://kbbi.kemdikbud.go.id/entri/wāli,

[20] Mardani, Hukum Keluarga Islam di Indonesia. Jakarta: Prenadamedia, 2016.

[21] Muhammad Abu Zahroh, al-Ahwāl al-Syakhșiyah. Beirut: Dar al-Fikr al-Arabiy.

[22] Ali ibn Muhammad al-Mawardi, al-Hāwi al-Kabīr. Beirut: Dar al-Kutub al-Ilmiyah.

[23] Muhammad ibn Ahmad ibn Muhammad ibn Ahmad ibn Rusyd, Bidāyah al-Mujtahīd wa Nihāyah al-Muqtașid. Beirut: Dar Ibn Hazm, 1995.

[24] Umar Said Sugianto, Pengantar Hukum Indonesia. Jakarta: SinarGrafika, 2014.

[25] Al-fayruz Abadi, al-Qāmus al-Muhīt. Beirut: Mu'assasah al-Risalah, 1987.

[26] Ahmad al-Raysuni, al-Fikr al-Maqāṣid Qawāiduh wa Fawāiduh. Ribath: Matba'ah al-Najah alJadidah Dar al-Baydha'.

[27] Sami' Abd al-Wahhab, Ahammiyah al-Maqāsid fi al-Sharī'ah al-Islāmiyah. Damaskus: Resalah Publisher, 2008.

[28] Asnawi, Perbandingan Ushul Fiqh. Jakarta: Amzah, 2011.

[29] Romli SA, Muqāranah al-Madhāhib fi al-Ușūl. Jakarta: Gaya Media Pratama, 1999.

[30] Nasrun Harun, Ushul Fiqh 1. Jakarta: Logos Wacana Ilmu, 1997.

[31] Ahmad al-Raysuni, Madkhāl ilā Maqāsid al-Sharī'ah. Kairo: Dar al-Kalimah, 2010.

[32] Hammady al-'Ubaidy, al-Shāțibi wa Maqāsid al-Sharī'ah. Beirut: Dar Qutaybah, 1996.

[33] Ahmad Arif Masdar Hilmy, "Disparitas Usia Minimal Perkawinan dalam Kompilasi Hukum Islam Perspektif Teori Batas Maṣlahah Said Ramaḍān al-Būṭi," Islam Nusantara, vol. III, no. 01, pp. 123-157, 2019.

[34] M. Yahya Harahap, Kedudukan Kewenangan dan Acara Peradilan Agama Undang-undang No. 7 tahun 1989. Jakarta: Pustaka Kartini, 1990.

[35] M. Karsayuda, Perkawinan Beda Agama: Menakar Nilai-Nilai Keadilan Kompilasi Hukum Islam. Yogyakarta: Total Media, 2006.

[36] Hindun Anisah Ratna Batara Munti, Posisi Perempuan dalam Hukum Islam di Indonesia. Jakarta: LBH-APIK, 2005. 